\title{
Impact of teachers' social capital on their professional performance: a narrative inquiry
}

\author{
Muhammad Rafiq | Abdul Ghaffar | Amir Zaman* \\ Department of Education, Abdul Wali Khan University, Mardan, Pakistan.
}

* Corresponding Author Emails: dr.amirzaman@awkum.edu.pk|amirzaman69@yahoo.com

\begin{abstract}
The purpose of this study was to explore the impact of social capital on teachers' professional performance. The participants were ten male subject specialists from government higher secondary schools of District Malakand, Khyber Pakhtunkhwa, Pakistan. The method of data collection was one-onone in person through in-depth interview. Teachers' narratives showed that teachers who had stronger social capital performed better their others. Performance of the teachers who showed high level of participation and willingness were those with high social capital. They were more interested in curricular and co-curricular activities that enhanced their professional performance. There is a strong bond of good relationship between teachers and students that was an efficient solution to meet the different needs of a classroom collectively as well as individual students, which impacts positively on students' learning and teachers' performance. There was no contribution from parents for success of the students. Owing to financial constraints, the parents were more inclined to engage their children for earning and part time job. Moreover, lack of awareness, jobless white collars in their surroundings, labouring and earning livelihood far away from home are the reasons that they take negligible interest in contributing to the success of their children.
\end{abstract}

\section{Article History}

Received:

September 24, 2020

Last Revised:

February 6, 2021

Accepted:

February 7, 2021

Published:

February 16, 2021

Keywords: social capital, dimensions of social capital, social capital in education, social capital in school, teachers' social capital, teachers' professional performance.

\section{How to Cite:}

Rafiq, M., Ghaffar, A. \& Zaman, A. (2021). Impact of teachers' social capital on their professional performance: a narrative inquiry. Liberal Arts \& Social Sciences International Journal (LASSIJ), 5(1), 1-15. https://doi.org/10.47264/idea.lassij/5.1.1

Copyright: @ 2021 The Author(s), published by IDEA PUBLISHERS (IDEA Journals Group)

This is an Open Access article published under the Creative Commons AttributionNonCommercial 4.0 International License (http://creativecommons.org/licenses/by-nc/4.0/)

Publisher's Note: IDEA PUBLISHERS (Journals Group) stands neutral with regard to the jurisdictional claims in the published maps and the institutional affiliations. 


\section{Introduction}

Social capital emphasizes the importance of social factors that are generally underestimated or ignored in the modern society with increasing focus on individuality, competitiveness and economic priorities. The term social capital was not until the 1990s, but it widely used during the $20^{\text {th }}$ century and began to spread rapidly in the social sciences, physical sciences and scientific research. Social capital is a complex, multifaceted concept that has different implications on different contexts (Shiell et al., 2020). It is the relationship of people that they have with themselves, neighbours, and in society as a whole (Aldrich \& Meyer, 2015). In organizations, it refers to the connection of members of organization that helps to facilitate in the development of both the members and organization. It also facilitates trust, norms and social links between individuals (Yoon \& Lee, 2019), and transfer of knowledge and development of intellectual capital among the members of organizations (Inkpen \& Tsang, 2005). However, the potential use of social relationships can use the social capital process positively to ensure demands on those who are in power for the provision of services, resources and support (Campbell, 2020). Moreover, importance is given to the real and potential benefits achieved through formal or informal relationships of an individual with others. Therefore, societies are glued together by social capital. In its absence, the societies collapse. School is also a part of society that consists inside on principal, teachers, students, and parents are its outer part. There is gap of research work on impact of social capital for this society in the research literature.

This research's aim is to address teachers' social capital in the form of relationship with the principal, colleagues, parents and students and how it impacts on their professional performance. This paper highlights the perceived gap in the research. The importance of teaching standards and quality has been recognized highly. To its wide range and importance in the teaching and learning, due attention has not been paid which has a great impact on the quality of teaching and learning. Social capital is one of these factors. This research paper has been designed in response to these gaps to explore the impact of teachers' social capital on their professional performance.

\section{Literature review}

\subsection{Social capital}

Social capital is used as a compound and multidisciplinary concept (Daykin et al., 2020). In the social sciences, it is a competing concept, which lacks a generally accepted definition (Waithaka, 2014). It is the relationships that people have with themselves, their neighbours, and their external relations in society as a whole. It also refers to the networks that affect the social and economic activities, and the social norms that create strong relationships within the community. Further, it is an asset which helps community development and enhancement (Aldrich \& Meyer, 2015). Similarly, communities mutually benefit from collaboration, connection and communication between its members (Cao et al., 2013). It has a beneficial impact on economic outcomes and norms (Moolenaar, 2015). Moreover, interactions produce beneficial outputs, which is likely to increase with higher levels of social capital. Therefore, social capital is the binding force that tie human societies and communities together, without which society may vanish away (Acar, 2011). Most of the existing literature reiterates that social capital is effective in improving the performance of the society. This is because the social 
capital is made up of a fabric of the social relationships and the networks based on trust, cooperation and others' respect which collectively facilitates integrated initiatives in the society (Bolton, 2011).

\subsection{Dimensions of social capital}

There are three dimensions of social capital. These dimensions are structural, cognitive and relational. These dimensions are conceptually different but interrelated in practice with each other. The structural social capital is found in the form of a network of accessibilities to people and other resources while the relational and the cognitive social capitals is the reflection of capability for exchanging resources (Andrews, 2010). Therefore, high levels of the social capital contain string connections, existence of high level of trust, and having a shared goals and desires. In other words, level, quality, nature and the extent of shared goal or vision of interconnectedness between individuals or groups of individuals determine the quality and social capital (Akram et al., 2016). From this interconnectedness, various dimensions of the social capital are related like, the structural which is connections among the actors, the relational that refers to trust between the actors, and the cognitive that refers to shared goals and values among the actors (Claridge, 2018).

\subsection{Social capital in education}

In educational context, social capital refers to three - way educator - parent - sponsorship (community) relationships and networking. Similarly in this context, social relationships between family, school and community lead to social capital (Aslandogan \& Cetin, 2007). Further, differences in student or educational achievement can be attributed to varying levels of existing social capital that develop in the networks and connections of families that occur in schools. Therefore, social capital supports success and education in the form of discipline and an academic climate at school, as well as support for cultural principles and values that motivate students to have the right to strive for higher goals. Similarly, the development of children and youth is strongly shaped by social capital in school (Putnam, 2000). Moreover, family structure, family discussion, parental supervision, parental relationships, family expectations and responsibilities, and parents' interactions with their children's school and friends contribute to students' academic achievement in a variety of ways (Dika \& Singh, 2002). This attraction also contributes to overall success in positive advertising and education, resulting in more parents, community and support. Furthermore, they argue that teachers who show and reflect these pointed out universal or moral values are far more effective than textbooks and teaching instruction. In addition, Sil (2007) looks at social networks in parent groups between parents and teachers that yield shared positive results for everyone in the school.

\subsection{Social capital in schools}

There is a growing body of literature that examines teachers' social capital and social network relationships of teachers that generates, improves, and combines to form professional learning groups and improves student achievement (Deal et al., 2008; Moolenaar, 2015). In schools, social capital plays an important role in predicting organizational performance of school and teaching quality (Pil \& Leana, 2009). Therefore, school leaders communicate and build relationships with teachers, and these associations work on relationships that may include resource transfers such as work-related information, advice, and community support (Daly et 
al., 2014; Pil \& Leana, 2009; Moolenaar, 2015). Furthermore, the social capital of schools is reflected in various aspects of the relationship between stake holders i.e., students, teachers and parents and which supports academic achievements and implications for its well-being (Parcel et al., 2010). Moreover, there are many studies that have indicated that higher social capital, at school, at home, or both, is related to better educational achievement (Dufur et al., 2013; Parcel et al., 2010) Similarly, better social capital in schools plays an important role in developing and predicting the organizational performance and teaching quality of schools (Pil \& Leana, 2009). Furthermore, the improvement of social capital in the educational context refers to the establishment of a tripartite educator-parent-sponsorship, relationship and networking. In this context, as well as parental expectations and responsibilities, social networks through family, school and community lead to social capital (Hunt \& Aslandogan, 2007). Furthermore, the tangible benefits of social capital for education can be seen in higher success on tests, higher graduate rates, lower education rates, higher college admissions, and high school participation and community organizations (Acar, 2011).

\subsection{Teachers' social capital}

The resources that teachers can access through peer collaboration to support their ongoing learning refers to social capital. Pedagogical concepts and structured conversations both are the potential sources of teachers' social capital. The resources are shared but its utilization depends on the individual teacher (Johnson et al., 2011). It provides a useful framework for understanding how teachers' relationships might affect their work, and theoretical and empirical work on social capital demonstrates how teachers' relationships might be related to their students' achievement. Teachers' social capital refers to teachers' relationships with other professionals and stake holders via teams, groups, and networks (within and outside of the school) that further enhance their practice and advance school goals (Hargreaves \& Fullan, 2012). Teachers' social capital has also been linked to their effective practice and positive student outcomes. Similarly, teachers' cohesiveness contributed to student achievement above and beyond teachers' years' of classroom achievement (Daly et al., 2014). The strength and reach of the relationships that teachers build within a school community are important because, through these relationships, teachers are able to access resources such as expertise or materials which allow them to improve their teaching. These resources, available through social interaction with colleagues, are known as teacher social capital (Coburn \& Russell, 2008). When people talk about improving education they often point to the need for tighter (or looser) teacher selection requirements, more or different teacher preparation, advanced degrees, additional credentials, etc. These are human capital factors, skills, knowledge or experience that belong to individuals. When fellows, it establishes collaborative practices in their schools, and they influence the development of social capital. In sum, teachers who occupy more central network positions (higher social capital) may have increased access to resources (e.g. information, reform-related knowledge and materials) that may support them in improving student performance (Pil \& Leana, 2009).

\subsection{Performance}

Performance is a form of behavior of an individual or an organization to achieve the desired goals and objectives. It refers to the degree of achievement of the goals or the potential achievement of stakeholders about the fundamental targets and features of an organization (Carey et al., 2011). Therefore, performance is defined primarily by a multidimensional set of 
standards. Its main source is the action of individual in his professional career. Additionally, performance is the overall result or success rate of a task over a given period of time compared to different tasks, such as quality of work, goals or standards that have been defined and agreed upon (Kuncoro \& Dardiri, 2017). Moreover, performance is a behavior related to an individual or members of organization to accomplish the pre-determined expectations, specific targets, or formal requirements of the organization (Bos-Nehles et al., 2013). This means that initiatives that directly or indirectly add value to the organization's ability, accomplishment and success, and the key to effective performance, are a skilled and motivated workforce. Furthermore, Chai (2009) favours the idea of implanting not only the financial features, but also the views of individuals involved in achieving environmental and social equity goals. This is a view that supports the need to change from a $3 \mathrm{E}$ (utility, efficiency, economy) system to a 5E type system (economy, efficiency, effectiveness, environment and equity). Similarly, Bartoli and Blatrix (2015) state that performance should be defined through matters like evaluation, piloting, performance, effectiveness and quality.

\subsection{Teachers' performance}

The performance of all the teaching activities and practice of teaching that a teacher performs in a classroom like asking questions, offering explanations, giving instructions, presentation and demonstration, engaging in various instructional activities refers to teaching performance (Rao, 2003). In addition, the performance of teachers is related to the actual time spent on teachers' educational activities (Chisholm et al., 2005). Furthermore, teacher performance also refers to the duties performed by teachers in a particular period of time in the school system (Adeyemi, 2010). In addition, it also includes the use of relevant efforts of teachers to combine together to enhance the teaching process (Riaz, 2000). It plays a vital and important role in the teaching-learning process. The development of a nation depends on education, which is possible through the performance of teachers. A growing empirical basis suggests that there is a positive correlation between teacher - student interaction and student achievement. Teacher needs more resources to enhance the students' learning and make their teaching effective. Teacher social capital is the best strategies that provide the related materials for effective performance. It can possibly be concluded that higher level of social relationships at school renders greater benefits. Developing social relationships between individuals through establishing social networks, interaction, reciprocity and coordination and cooperation and efficiency in collective tasks with higher sense of trust are the possible positive impacts of social capital (Grootaert et al., 2004).

\section{Research methodology}

A narrative inquiry paradigm is used in this study to explore the impact of teachers' social capital on their professional performance. Narrative paradigm as a method of exploration involves understanding and interpretation of the phenomenon in the study (Clandinin, 2006). In narrative design, stories can be very useful because they allow to see what the actual life experience can do with the people who are living that experience and also providing knowledge that is enthusiastically place in the world (Webster \& Mertova, 2007). In this research study, an in-depth one-on-one interview is used as a research tool to get an in-depth perspective of participants' experiences in relation to a particular phenomenon (Riessman, 2008). The researcher carefully reviewed the audio and written files and created the transcripts with great care based on lived experiences of the participants. 


\subsection{Participants}

The researcher identified ten male subject specialists namely Anwar, Umar, Iftikhar, Ayaz, Nasir, Mubashir. Naveed, Zamin, Farman and Sajjad of five government higher secondary schools Kot, Ghani Dheri, Sakhakot, Khar Batkhela, and Dheri Julagram of District Malakand, Khyber Pakhtunkhwa, Pakistan. Four teachers belong to the subject of English, one Chemistry, one History Cum Civics, one Mathematics, two Physics and one Islamiat All teachers possess minimum nine years of total teaching experience. Moreover, the identity of the participants was kept confidential by using pseudonyms instead of using their personal names in the study. This is a qualitative inquiry that seeks to understand the meaning of a context from a participant's point of view. Therefore, it was essential to select participants who can devote sufficient time and share in-depth information and experiences. With the researcher's background and experiences in education as a subject specialist, professional role as a subject specialist in many educational institutions for more than a decade, the researcher has the ability to narrate the participants' stories, constructed credibility with the participants, and know and comprehend the context when interpreting the data (Creswell, 2017). As the researcher himself is a basic data collector, therefore, having a bond with the participants becomes an unavoidable task. As per the demand of the research ethics, the researcher obtained formal consent from the participants for interviewing them.

\subsection{Limitation of the study}

This study was conducted on male teachers because, close relationship between the researcher and the participants is the essential of narrative design. The structure of our society and cultural restriction does not allow liberty of interaction to female teachers. Therefore, one of the limitations of the study was that only male participants were interviewed for data collection purposes besides of particular importance of exploration of female teachers. It is pertinent that this limitation would have a gender specific impact on study's findings. Furthermore, this research study had a definite geographical limitation with regard to the participants of the study. The narratives are drawn only from the teachers within the surrounding of District Malakand, a rural area in nature. Teachers of other districts and urban teachers may have upper hand in socialization and different social capital. In addition, the participants belonged only to higher secondary schools, teachers of other levels are not participated. It is possible that the situation may different at other levels.

\section{Analysis and discussion}

Narrative analysis was used to develop an in-depth perspective of participants' experiences in relation to a particular context (Riessman, 2008). Furthermore, narratives provide windows in life that confront the limitations of situations. In this study, participants' narratives were also analysed to find different stories concerning their actual life experiences. The researcher paid careful attention to the representation of what was heard and communicated with participants, and basically strengthened the boundary between speech and writing. Seven of the participants Anwar, Umar, Ayaz, Mubashir, Zamin, Farman and Sajjad construct their relationship with the principal around the idea of friendly relationship between principal and teacher. They consider it essential for their duty. They narrated, "We are in favour of keeping good relationship with the principal regarding their dignity and authority". When asked why? They narrated, "Such kind of relationship never creates problems and hurdles. Whatever we need regarding our 
subject and teaching, we contact with the principal for assistance". Answering to the question, how do your principal favour and encourage you, they narrated, "They encourage us whenever we discuss relevant matters regarding the needs and requirements of our subject and teaching". They said that they communicate students' classroom and students' problems with the principals. They described, "We feel no hesitation and freely share classroom and students" problems with the principal". For them, "Principal of the school encourage and facilitate them, and honour their opinions in this connection". Teachers' relationship with the principal is essential for their job performance. They are in favour to keep relationship with their principals regarding their dignity and authority because such kind of relationship never creates problems and hurdles.

In addition, Moolenaar study (2015) also concluded that relationships between teachers and head of the school develops from their interaction with each other for transferring work-related ideas and information, resources, advice and for getting social support in certain matters. Three of the participants Iftikhar, Nasir and Naveed described that there is lack of good relationship between them and principals of their schools. Iftikhar and Naveed who teaches in one school, described, "Principal of the school keeps distance with the teaching staff. His behaviour is harsh and unfriendly". When asked why? They narrated, "He is a landlord and considers himself superior over the teaching staff. He treats them as his personal servants and peasants. His behaviour is merely authoritative. The school environment is not favourable for team work. Due to lack of encouragement and friendly relationship, their relations with the principal do not improve their professional performance". When asked how do you feel in such environment? They narrated, "We do not feel relax in such a tensed environment and feel boredom". Nasir described, "behaviour of my school principal is authoritative and always imposes his own decisions ignoring ground realities and without the consultation of teachers". When asked how? He narrated, "He follows the philosophy of Khanism (code of conduct based on autocracy and Monarchianism headed by local chieftain)". Answering to a question that whether it impacts you, he narrated, "Non-cooperation, taking no interest in the solution of classroom problems and facilitation, bad relationship, tensed environment, creation of problems, biased and authoritative behaviour of the principal badly impacted my professional performance". He also told that he tried his best and extended variously his cooperation, but he did not show positive response. Nasir told with sorrow, "This is the worst experience of my profession".

Nine of the participants Anwar, Umar, Iftikhar, Ayaz, Nasir, Mubashir. Naveed, Zamin, Farman and Sajjad narrated their relationship with colleagues, "We feel no hesitation in sharing problems with colleagues". When asked how, they narrated, "We openly share and get proper guidance, help and support. We share subject, classroom and students' individual problems with colleagues. We improve our knowledge of subject through the sharing of problems regarding our subject and discussion with colleagues. We get a lot of help in pronunciation, and improving vocabulary and subject matters. We get a lot of materials from them." Moreover, they narrated, "We get useful tips and techniques from colleagues. If we face some sort of problems, we discuss it with our colleagues. They provide the guidance to solve the problem. It has shown us fruitful results in our teaching career. It improves our knowledge of subject with the collaboration. We take help from them in those topics/contents and matters which are not clear to us. Sometimes, topics are related to other subjects in which we take details from the colleagues in those topics". Only one respondent Sajjad said that one's own competencies are sufficient for professional enhancement. He narrated, "I do not collaborate in planning with 
colleagues in curricular and co-curricular activities because I do not feel their need". When asked why, he said "Colleagues have no role in my professional performance. I face and handle all kind of environment myself". Answering to a question how, Sajjad narrated, "They are in search of opportunity to disgrace their colleagues, share the staffroom talks and gossip with authorities. If one is doing any positive activity in school, they oppose him. They play the role of dog in the mongrel. They do not agree with others and thus, the whole plan is destroyed". The professional experiences of the participants show that developing friendly relationship with colleagues establishes better social capital. This result is in line with the studies of Hargreaves and Fullan (2012), Molinari and Sleegers (2014), and Deal et al. (2009).

All participants feel that with extreme bad luck, most of the parents are illiterate and they know nothing about their children's education. Most of the parents even did listen to us, but do not extend their cooperation. They narrated, "Parents are poor and having no time for educating their children. There is a lack of awareness about the fruits of education among the parents. They just fulfil their duty by admitting and sending their children to school. Approximately, all the parents do the same. The negligible ratio of the parents or guardians support is contributing to the success of their children". Narrating their efforts to ensure the cooperation of parents, they told, "They have followed a number of strategies to convince them and provided a number of information to the parents of the students, but fruitless Almost, parents take no interest in their children's learning as and they do not take any interest. With extreme bad luck, their responses in most cases are very negative." When asked why, they narrated, "The reason behind is the lower economic background relying on daily wages and illiteracy of the parents". Iftikhar narrated, "Parents of the students are far away from home in the country or in foreign countries mostly in KSA and UAE. Most of the students belong to labour class. They are also busy in labouring with their parents." Ayaz narrated, "Once in 2016, after an extensive search, I got the cell number of the father of one of my students who was absent from school for ten days. When I asked the father of the student that his son was not coming to school for many days. The father replied "Go to hell with you and your school, I have bought a Reksha (a local transport)" for my son to earn livelihood for the family". Nasir described, "if father is away from home and mother informed, she does not communicate the message to father". When asked how, he said, "According to the tradition, children do not feel fear from mothers. If father asks from the mother about the academic position of his children, she does not provide the exact information to him". Naveed further narrated, "Lack of awareness, jobless white collars in their surroundings, labouring and earning livelihood far away from home are the reasons that they take negligible interest in contributing to the success of their children. Parents feel satisfaction and happiness mere that their children are enrolled in the school. Furthermore, they take no interest in their children's education". Zamin narrated, "Most of the parents, after passing their children HSSC examination, try their best to recruit their children in security forces or send them abroad especially to UAE or KSA for earning livelihood". Furthermore, good relationship with parents for teachers enhances their professional performance. This was also concluded by Shahidul et al. (2015), and Parcel et al. (2010) and in their studies. But the teachers narrated that the parents do not keep their relationship with teacher, which badly impact their professional performance.

Nine of the participants Anwar, Umar, Iftikhar, Ayaz, Nasir, Mubashir. Naveed, Zamin and Farman narrated their relationship with students, "We keep friendly relationships with our students. We give them due respect, call them by name and, son and nephew. As a result, they pay respect, show obedience and good results in their subject. We tell them that you are very 
important in school. We are appointed for you and all our efforts are for you". As a reward of friendly relationships, they narrated, "students feel easy, loss their fear, ensure their participation and involvement, ask and put question without hesitation, give answers to his questions, express their opinions, their hidden potentials and creativity is developed. It develops self-confidence, pay respect, remain attentive to class, and focus totally on teaching". Zamin narrated, "I keep my behaviour and relationships with students friendly and reliable based on trust that they share their problems with me without any fear or hesitation. Most of the mothers of the students keep no "Purdah" due to my reliable and trustworthy relationships. If any of my students became ill, I go to his home for his Bemarpursi (ask after). I also help them from my own pocket sources. Students and their parents consider me as their family member. They invite me and consider my presence as a proud in celebrating their any kind of gatherings, events and functions". When asked why, he said, "While keeping too much gap, students will not share and discuss their problems. They will feel fear and hesitation". Farman narrated, "I try my level the best to meet the needs of all my students. I discourage gap with students". Sajjad favours gap and narrated, "many times friendly relationship may cross the boundary of morality and ethics. Students may become free and disturb the class environment". Naveed also favours gap in the sense that not more than teaching, learning and classroom problems may be discussed and shared. He narrated, "Students have many social, moral, cultural and economic problems. I keep gap not to share and discuss these problems. It diverts my concentration from my main goals and objectives. Besides, my job is not to know and solve these problems. To some extent, I allow the students to share, but not at all. Gap make students obedient and reasonable. When there is a gap, then students ask and share only subject and classroom problems and do not waste time in irrelevant discussion and matters. They concentrate over their content and subject matter. They remain in the circle of respect". Friendly relationship with their students. While, in keeping gap, students feel fear. They do not ask question, nor express their opinions. Therefore, self-confidence is not developed. It helps in maintaining the dignity of the teacher and student relationship. Teachers can access through peer collaboration to support their ongoing learning. This finding is in line with the findings by Johnson et al. (2011), Coburn and Russell (2008), and Penuel et al. (2009). Similarly, teachers who occupy more central network shows better performance which was also reported by Penuel et al. (2010) and, Pil and Leana (2009).

The summary in the table- 1 shows that all the teachers favour relationship with principal for the enhancement of professional performance. Seven of the respondents have good relationship with their principals. They communicate and share classroom problems and sort out solution to the problems in collaboration. Three of the respondents narrated lack of good relationship due to the authoritative and harsh behaviour of their schools' principals. Adversely, there is communication gap and also lack of collaboration between them. Nine of the teachers are agreed on the collaboration with colleagues for the enhancement of professional performance. However, only one teacher didn't favour collaboration with colleagues for professional performance and reported that one's personal competency is sufficient. On the question regarding relationship with parents, all teachers consider good relationship with parents for their professional performance but contrary to it, the parents do not keep their relationship with teachers, which badly impact their professional performance. Similarly, eight of the teachers consider friendly relationship with students for professional performance whereas only two teachers opposed the notion of friendly relationship with students due to their immaturity who may become free and disturb the class environment. 
Table 1: Cross-Case Analysis of Commonalities and Differences Amongst the Teachers Based on the Participants' Stories:

\begin{tabular}{|l|l|}
\hline Commonalities & Differences \\
\hline Relationship with Principal & $\begin{array}{l}\text { - Seven of the respondents have good relationship with their } \\
\text { principals. They communicate and share classroom } \\
\text { problems and sort out solution to the problems in } \\
\text { collaboration. }\end{array}$ \\
\hline $\begin{array}{l}\text { All the respondents favour } \\
\text { relationship with the principal for the } \\
\text { enhancement of professional } \\
\text { performance. }\end{array}$ & $\begin{array}{l}\text { Three of the respondents narrated lack of good relationship } \\
\text { due to the authoritative and harsh behaviour of their } \\
\text { schools' principals. Adversely, there is communication gap } \\
\text { and also lack of collaboration between them. }\end{array}$ \\
\hline $\begin{array}{l}\text { Relationship with Colleagues } \\
\text { Nine of the respondents are agreed on } \\
\text { the collaboration with colleagues for } \\
\text { the enhancement of professional } \\
\text { performance. }\end{array}$ & $\begin{array}{l}\text { Only one respondent says that one's own competencies are } \\
\text { sufficient for professional enhancement. Colleagues have no } \\
\text { role in professional performance. }\end{array}$ \\
\hline Relationship with Parents & $\begin{array}{l}\text { All of the respondents consider good } \\
\text { relationship with parents for their } \\
\text { professional performance but the } \\
\text { parents do not keep their relationship } \\
\text { with teacher, which badly impact } \\
\text { their professional performance. }\end{array}$ \\
\hline $\begin{array}{l}\text { Relationship with Students } \\
\text { Eight of the respondents consider } \\
\text { friendly relationship with students for } \\
\text { professional performance. }\end{array}$ & $\begin{array}{l}\text { Two respondents are opposed due to immaturity of students } \\
\text { Who may become free and disturb the class environment. } \\
\text { and classroom problems and do not waste time in irrelevant } \\
\text { discussion and matters. They concentrate over their content } \\
\text { and subject matter. They remain in the circle of respect. }\end{array}$ \\
\hline
\end{tabular}

\section{Conclusion}

Teachers' narratives reveal that healthy relationship of teachers with principal enhances the professional performance of teachers, because they can share and discuss classroom problems with the principal freely. Additionally, such kind of relationship never creates problems and hurdles. Similarly, the study reveals that promoting positive relationship with the colleagues have positive impact on teachers' professional performance. The findings of the study conclude that relationship with colleagues enhances the team work which promote the collaborative network in school. It is further concluded that it enhances the competencies of teachers. Moreover, parents are the main stack holders in education process. Parents play a vital role in in the enhancement of students learning. The conclusion of this study is that good relationship with the parents promotes the professional performance of teachers due to feedback from parents. In contrast, non-involvement of parents badly impacts their professional performance. Owing to financial constraints, the parents were more inclined to engage their children for earning and part time job. Moreover, lack of awareness, jobless white collars in their 
surroundings, labouring and earning livelihood far away from home are the reasons that they take negligible interest in contributing to the success of their children. Further, students are the backbone of the whole education system. To motivate the students towards learning is the main function of teachers. This study also concludes that developing a friendly environment in the classroom and good relationship also provide opportunity to the teachers for their professional development in the sense that students frankly can share with teachers that which ways best for them to learn and thus, teachers can improve their methods and techniques of teaching.

\subsection{Recommendations}

The study recommends that principal of the school may pay attention to the factors that create the conditions by which teachers' social capital may flourish. When school principal acknowledges school's important stake holders, the teacher and the student can benefit greatly. Furthermore, department of E\&SE and principal of the school may pay attention to the factors that create environment by which teacher social capital may flourish. Additionally, connections between families, communities and schools may be needed to be built to contribute not only the schools' effectiveness, functioning and academic success of the students, but also the professional performance of teachers. Moreover, parents or guardians may be made responsible through legislation to contact teachers and response positively, when informed by the school.

\subsection{Direction for future research}

The present study concerns the male teachers only. The close interaction between researcher and participants is a prerequisite. Our society allows only liberty with male gender. Therefore, a study may be conducted by a female researcher for focusing on the female gender. Furthermore, the narratives are drawn only from the teachers within the surrounding of District Malakand, a rural area in nature. Similar study may be conducted in other districts of urban areas. In addition, the participants belonged only to higher secondary schools, similar study may be conducted at other levels.

\section{References}

Adeyemi, T. (2010). The supply of science teachers to secondary schools in Ondo state, Nigeria: a critical analysis. African Journal of Educational Studies in Mathematics and Sciences, 7(1). https://doi.org/10.4314/ajesms.v7i1.68915

Acar, E. (2011). Effects of social capital on academic success: a narrative synthesis. Educational Research and Reviews, 6(6), 456-461. https://doi.org/10.5897/ERR.9000134

Adams, R. (2008). Review of Riessman (2008): Narrative methods for the human sciences. Narrative Inquiry, 18(2), 415-418. https://doi.org/10.1075/ni.18.2.13ada

Aldrich, D. P., \& Meyer, M. A. (2014). Social capital and community resilience. American Behavioural Scientist, 59(2), 254-269. https://doi.org/10.1177/0002764214550299

Akram, T., Lei, S., Hussain, S. T., Haider, M. J., \& Akram, M. W. (2016). Does relational leadership generate organizational social capital? a case of exploring the effect of relational leadership on organizational social capital in China. Future Business Journal, 2(2), 116-126. https://doi.org/10.1016/j.fbj.2016.06.001

Andrews, R. (2010). Organizational social capital, structure and performance. Human Relations, 63(5), 583-608. https://doi.org/10.1177/0018726709342931 
Aslandogan, Y. A., \& Cetin, M. (2007). The philosophy of Gulen in thought and practice. https://doi.org/10.5040/9781472552693.0006

Bartoli, A., \& Blatrix, C. (2015). Management dans les organisations publiques, Dunod. Management international, 13(4), 135. https://doi.org/10.7202/038593ar

Bolton, D. J. (2011). Social capital in rural southwest Kansas. Kansas State University. 3(5). https://doi.org/10.4148/2378-5977.7416

Bos-Nehles, A. C., Van Riemsdijk, M. J., \& Kees Looise, J. (2013). Employee perceptions of line management performance: applying the AMO theory to explain the effectiveness of line managers' HRM implementation. Human Resource Management, 52(6), 861877. https://doi.org/10.1002/hrm.21578

Campbell, C. (2020). Social capital, social movements and global public health: Fighting for health-enabling contexts in marginalised settings. Social Science \& Medicine, 257, 112153. https://doi.org/10.1016/j.socscimed.2019.02.004

Cao, Q., Lu, Y., Dong, D., Tang, Z., \& Li, Y. (2013). The roles of bridging and bonding in social media communities. Journal of the American Society for Information Science and Technology, 64(8), 1671-1681. https://doi.org/10.1002/asi.22866

Carey, S., Lawson, B., \& Krause, D. R. (2010). Social capital configuration, legal bonds and performance in buyer-supplier relationships. Journal of Operations Management, 29(4), 277-288. https://doi.org/10.1016/j.jom.2010.08.003

Cetin, M. (2007). The Gulen Movement: its nature and identity. Paper presented at the conference, Muslim World in Transition: Contributions of the Gulen Movement. University of London. https://doi.org/10.5040/9781472552693.0006

Coburn, C. E., \& Russell, J. L. (2008). District policy and teachers' social networks. Educational Evaluation and Policy Analysis, 30(3), 203-235. https://doi.org/10.3102/0162373708321829

Claridge, T. (2018, January 20). Structural, cognitive, and relational social capital. Social Capital Research. https://www.socialcapitalresearch.com/structural-cognitiverelational-social-capital/

Chai, N. (2009). Sustainability balanced scorecard of SPES. Sustainability Performance Evaluation System in Government, 81-117. https://doi.org/10.1007/978-90-4813012-2_4

Chisholm, J. S., Quinlivan, J. A., Petersen, R. W., \& Coall, D. A. (2005). Early stress predicts age at menarche and first birth, adult attachment, and expected lifespan. Human Nature, 16(3), 233-265. https://doi.org/10.1007/s12110-005-1009-0

Clandinin, D. J. (2006). Narrative inquiry: A methodology for studying lived experience. Research Studies in Music Education, 27(1), 44-54. https://doi.org/10.1177/1321103x060270010301

Creswell, J. D. (2017). Mindfulness interventions. Annual Review of Psychology, 68(1), 491516. https://doi.org/10.1146/annurev-psych-042716-051139

Daly, A. J., Liou, Y., \& Der-Martirosian, C. (2020). A capital idea: Exploring the relationship between human and social capital and student achievement in schools. Journal of Professional Capital and Community, 6(1), 7-28. https://doi.org/10.1108/jpcc-102020-0082

Daykin, N., Mansfield, L., Meads, C., Gray, K., Golding, A., Tomlinson, A., \& Victor, C. (2020). The role of social capital in participatory arts for wellbeing: Findings from a qualitative systematic review. Arts \& Health, 1-24. https://doi.org/10.1080/17533015.2020.1802605 
Deal, T. E., Purinton, T., \& Waetjen, D. C. (2008). Making sense of social networks in schools. Corwin Press. https://us.corwin.com/en-us/nam/book/making-sense-socialnetworks-schools

Dika, S. L., \& Singh, K. (2002). Applications of social capital in educational literature: A critical synthesis. Review of Educational Research, 72(1), 31-60. https://doi.org/10.3102/00346543072001031

Dufur, M. J., Parcel, T. L., \& Troutman, K. P. (2013). Does capital at home matter more than capital at school? Social capital effects on academic achievement. Research in Social Stratification and Mobility, 31, 1-21. https://doi.org/10.1016/j.rssm.2012.08.002

Grootaert, C., Narayan, D., Jones, V. N., \& Woolcock, M. (2004). Measuring social capital: An integrated questionnaire. World Bank Working Papers. https://doi.org/10.1596/08213-5661-5

Hargreaves, A., \& Fullan, M. (2012). Professional capital: transforming teaching in every school. Teachers College Press.

Hunt, R. A., \& Aslandogan, Y. A. (2007). Muslim Citizens of the globalized world. contributions of the Gülen Movement. Tughra Books. https://doi.org/10.5040/9781472552693.0006

Inkpen, A. C., \& Tsang, E. W. (2005). Social capital, networks, and knowledge transfer. Academy of Management Review, 30(1), 146-165. https://doi.org/10.5465/amr.2005.15281445

Johnson, W., Lustick, D., \& Kim, M. (2011). Teacher professional learning as the growth of social capital. Current Issues in Education, 14(3). https://cie.asu.edu/ojs/index.php/cieatasu/article/view/781

Kuncoro, T., \& Dardiri, A. (2017). Teacher performance and work environment in the instructional process in vocational school. https://doi.org/10.1063/1.5003526

Moolenaar, N. M., \& Sleegers, P. J. (2015). The networked principal: Examining principals' social relationships and transformational leadership in school and district networks. Journal of Educational Administration, 53(1), 8-39. https://doi.org/10.1108/jea-022014-0031

Parcel, T. L., Dufur, M. J., \& Cornell Zito, R. (2010). undefined. Journal of Marriage and Family, 72(4), 828-846. https://doi.org/10.1111/j.1741-3737.2010.00733.x

Penuel, W., Fishman, B. J., Gallagher, L. P., Korbak, C., \& Lopez-Prado, B. (2009). Is alignment enough? Investigating the effects of state policies and professional development on science curriculum implementation. Science Education, 93(4), 656677. https://doi.org/10.1002/sce.20321

Pil, F. K., \& Leana, C. (2009). Applying organizational research to public school reform: The effects of teacher human and social capital on student performance. Academy of Management Journal, 52(6), 1101-1124. https://doi.org/10.5465/amj.2009.47084647

Putnam, R. D. (2000). Bowling alone. Proceedings of the 2000 ACM conference on Computer supported cooperative work - CSCW '00. https://doi.org/10.1145/358916.361990

Rao, D. (2003). Job satisfaction of school teachers. Discovery.

Riaz, M. N. (2000). Student evaluation of university teaching quality: Analysis of a teacher's rating scale for a sample of university students. Pakistan Journal of Psychological Research, 107-117.

Riessman, C. K. (2007). Narrative methods for the human sciences. Sage.

Shahidul, S. M., Karim, A. H., \& Mustari, S. (2015). Social capital and educational aspiration of students: Does family social capital affect more compared to school social capital? International Education Studies, 8(12), 255. https://doi.org/10.5539/ies.v8n12p255 
Shiell, A., Hawe, P., \& Kavanagh, S. (2020). Evidence suggests a need to rethink social capital and social capital interventions. Social Science \& Medicine, 257, 111930. https://doi.org/10.1016/j.socscimed.2018.09.006

Sil, S. (2007). Parent-School Partnerships: Forked Roads to College Access. School Community Journal, 17(1), 113-128.

Waithaka, E. N. (2014). Family capital: Conceptual model to unpack the intergenerational transfer of advantage in transitions to adulthood. Journal of Research on Adolescence, 24(3), 471-484. https://doi.org/10.1111/jora.12119

Webster, L. (2007). Using narrative inquiry as a research method. https://doi.org/10.4324/9780203946268

Yoon, S., \& Lee, E. (2019). Social and psychological determinants of value Co-creation behavior for South Korean firms. Asia Pacific Journal of Marketing and Logistics, 31(1), 14-36. https://doi.org/10.1108/apjml-01-2018-0017 


\section{Annexures:}

Annex-A: Table Showing Demographic Information of Respondents

\begin{tabular}{|c|c|c|c|c|c|c|c|}
\hline No. & Gender & Age & $\begin{array}{l}\text { School } \\
\text { Name }\end{array}$ & $\begin{array}{l}\text { Highest } \\
\text { Qualification }\end{array}$ & $\begin{array}{l}\text { Subject of } \\
\text { Appointment }\end{array}$ & $\begin{array}{l}\text { Total } \\
\text { Experience }\end{array}$ & $\begin{array}{l}\text { Subject Specialist } \\
\text { Experience }\end{array}$ \\
\hline $\mathrm{R}-1$ & \multirow{10}{*}{ Male } & 39 & Ghani Dheri & $\begin{array}{l}\text { MPhil Education } \\
\text { MA English }\end{array}$ & English & 12 years & 09 years \\
\hline $\mathrm{R}-2$ & & 51 & $\begin{array}{l}\text { Khar } \\
\text { Batkhela }\end{array}$ & $\begin{array}{l}\text { PhD Education } \\
\text { MSc Chemistry }\end{array}$ & Chemistry & 26 Years & 05 Years \\
\hline $\mathrm{R}-3$ & & 45 & $\begin{array}{l}\text { Dheri } \\
\text { Julagram }\end{array}$ & $\begin{array}{lr}\text { MA } & \text { History } \\
\text { MA Pol. Science }\end{array}$ & $\begin{array}{l}\text { History-cum- } \\
\text { Civics }\end{array}$ & 24 Years & 09 Years \\
\hline $\mathrm{R}-4$ & & 39 & $\begin{array}{l}\text { Khar } \\
\text { Batkhela }\end{array}$ & MA English & English & 18 Years & 02 Years \\
\hline $\mathrm{R}-5$ & & 42 & $\begin{array}{l}\text { Khar } \\
\text { Batkhela }\end{array}$ & MPhil Math & Math & 10 Years & 10 Years \\
\hline R-6 & & 49 & Ghani Dheri & $\begin{array}{l}\text { PhD Education } \\
\text { MSc Physics }\end{array}$ & Physics & 22 Years & 12 Years \\
\hline $\mathrm{R}-7$ & & 40 & $\begin{array}{l}\text { Dheri } \\
\text { Julagram }\end{array}$ & MPhil Physics & Physics & 12 Years & 09 Years \\
\hline $\mathrm{R}-8$ & & 41 & Kot & MA Islamiat & Islamiat & 09 Years & 09 Years \\
\hline R-9 & & 38 & Sakhakot & $\begin{array}{ll}\text { MA } & \text { English } \\
\text { MA } & \text { History } \\
\text { MA Pol. } & \text { Science } \\
\end{array}$ & English & 15 years & 08 years \\
\hline $\mathrm{R}-10$ & & 39 & Ghani Dheri & MA English & English & 11 Years & 03 Years \\
\hline
\end{tabular}

\section{Annex-B: Interview Guide/Schedule}

1. How does social capital impact teachers' professional performance?

2. How does your relationship with the principal impact your professional performance?

a. How do you label your ties with your principal?

b. How far do your principal favours and encourages you?

c. How often do you communicate on students' classroom problems with your school principal?

d. How do your relations with your principal improve your professional performance?

3. How does your relationship with colleagues' impact your professional performance?

a. How do you share classroom problems with colleagues?

b. How much support do you get from your colleagues to make the classroom environment and climate conducive for teaching learning process?

c. How much time do you have to collaborate in planning with colleagues in co-curricular activities?

d. How do you improve your knowledge of subject through collaboration with colleagues?

4. How does your relationship with parents' impact your professional performance?

a. How much support do you get from parents or guardians in contributing success of your students?

b. How do you encourage parents' involvement?

c. What kind of information you provide to parents about students?

d. What fruitful results have you observed from the sharing of these information?

5. How does your relationship with students impact your professional performance?

a. What strategy and techniques do you follow to get familiar with your students?

b. How much do you favour friendly relationships with your students?

c. How much do you favour gap with your students?

d. What benefits (advantages) you observe while keeping the gap?

e. What limitations do you observe? 